\title{
Odynophagia due to an unusual foreign body in the submandibular space
}

\author{
Kumar Nilesh
}

Oral \& Maxillofacial Surgery, Krishna Institute of Medical Sciences Deemed University, Karad, India

\section{Correspondence to} Dr Kumar Nilesh; drkumarnilesh@yahoo.com

Accepted 20 May 2020

\section{DESCRIPTION}

A 36-year-old man presented to the oral surgery clinic with a primary symptom of pain on deglutition (odynophagia) over left side of face since past 1 week. Severity of the pain increased during mastication and swallowing. No history of trauma to the face was reported. Medical history of the patient was unremarkable. Extraction of lower left molar teeth was done 5 years ago, which was uneventful. On clinical examination, no significant extraoral or intraoral findings were noted, except for tenderness over the lower left region of face, below the angle of mandible. No evidence of penetrative injury was identified on initial evaluation. For further clinical assessment, the patient was referred to ear, nose and throat clinic. No positive clinical findings were noted in the oropharynx. Imaging using CT with contrast was advised to study the jawbone and the surrounding soft tissue. The sectional and threedimensional formatted images of CT scan showed a linear radiopacity measuring $2 \mathrm{~cm}$, below the left posterior floor of the mouth, in the submandibular space (figure 1). Although the foreign material could not be exactly identified, it appeared like a metallic wire. In view of the imaging finding, patient was again questioned about the history of penetrating injury in the immediate past, which he denied to. On further enquiry, patient revealed habit of peeling off electric wire sheaths with his teeth while doing routine household electrical work.

Patient was informed about the imaging finding and was prepared for surgical removal of the foreign body under general anaesthesia. The choice of surgical approach included either intraoral incision over the floor of the mouth or an extraoral incision in the upper neck crease. After discussion with the patient, choice of an extraoral approach was made.
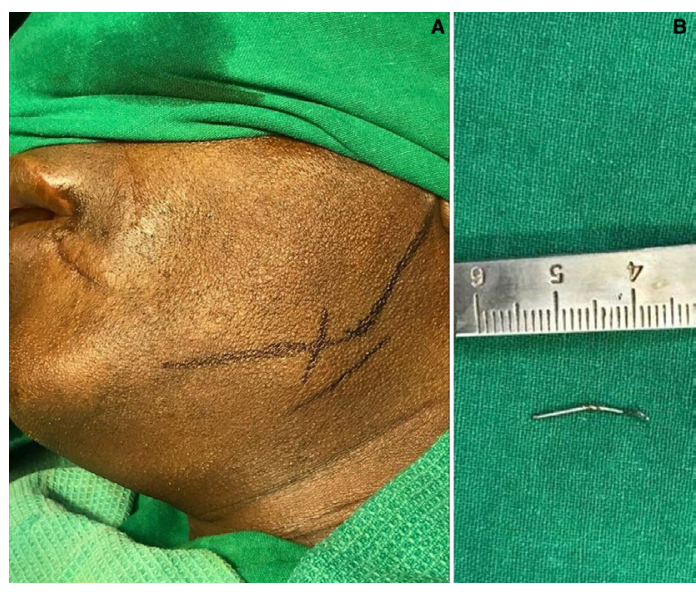

Figure 2 Intraoperative images showing, submandibular incision placed in the upper skin crease, about $1.5-2 \mathrm{~cm}$ below the lower border of mandible (A) and removed foreign body (B).

The extraoral approach provide direct access to the foreign body, which was located close to the lower border of mandible in the submandibular space. Use of intraoral approach in this situation would have required greater surgical dissection with possible risk of damage to vital structures in the floor of mouth, including sublingual gland, submandibular duct and lingual nerve and vessels. Submandibular incision was placed in the upper neck skin crease, below the left angle of the mandible (figure 2A). Risk of damage to marginal mandibular branch of the facial nerve through this approach was preoperatively explained to the patient and a written informed consent was obtained for the same. To reduce the risk of nerve damage, dissection was done in subplatysmal plane. The skin flap was
(D) Check for updates

(c) BMJ Publishing Group Limited 2020. No commercial re-use. See rights and permissions. Published by BMJ.

\begin{tabular}{l}
\hline To cite: Nilesh K. BMJ Case \\
Rep 2020;13:e235497. \\
doi:10.1136/bcr-2020- \\
235497
\end{tabular}
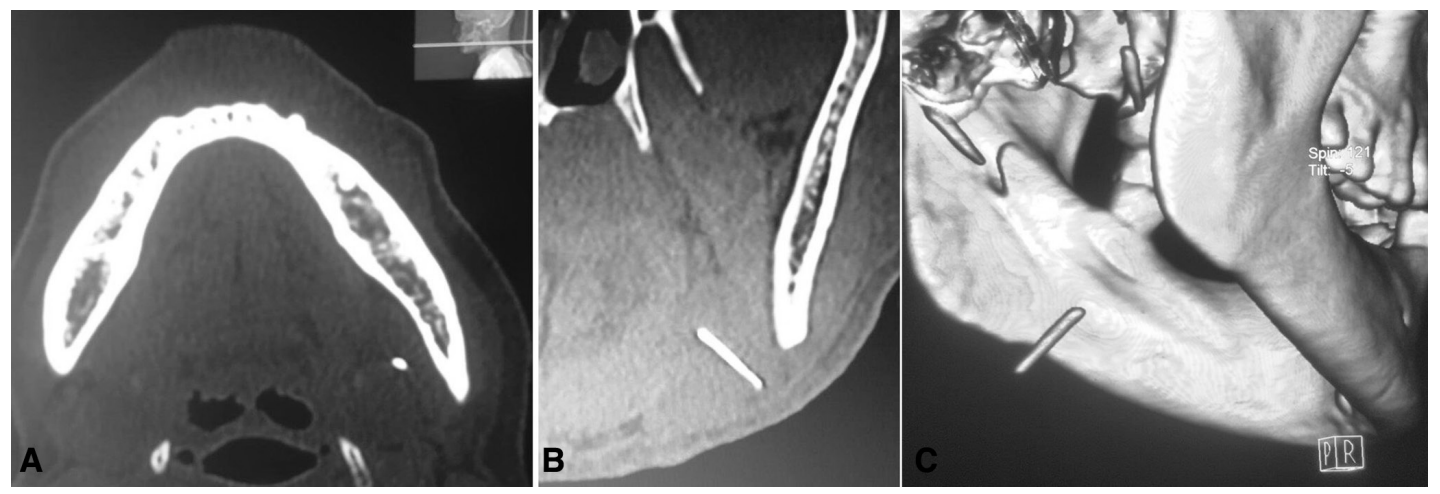

Figure 1 Axial (A) and coronal (B) sections of CT image showing presence of radiopaque material at the lower border on mandible in the angle region. Three-dimensional formatted image showing a liner foreign body in the submandibular space (C). 


\section{Patient's perspective}

The pain on eating and swallowing was a constant problem for me over the previous one week for which doctors were saying no findings were present. I had never fathomed that a simple careless habit of stripping the electric wire for my household work would land me at the operating table. Strangely, I do not remember the wire poking into my body. However, I did have it logged into my floor of mouth as my doctor showed it to the CT scan. The surgical removal has given me complete relief and I no longer use my teeth to strip off my wire sheath anymore!

reflected. Blunt exploration was done and a metallic foreign body was localised within the outer capsule of submandibular gland at its posterior aspect. The metallic wire was held with a haemostat and gently retrieved (figure $2 \mathrm{~B}$ ). The surgical site was closed in layers. The patient had uneventful postoperative healing period with resolution of all the symptoms.

\section{Learning points}

- Unrecognised trauma from sharp pointed objects in the orofacial region with foreign body logged within the soft tissue of floor of mouth and submandibular gland is rare, and usually present as pain and sialadenitis. Such foreign objects may also cause odynophagia. The common differential diagnosis for odynophagia includes; sialolithiasis, jaw tumours, muscle spasm and oesophageal strictures. Odontogenic infection resulting in submandibular abscess, can also present with odynophagia.

- Confirmation of foreign body in soft tissue can be attained using various imaging modalities including plain radiography, ultrasonography, CT, MRI and C-arm fluoroscopy.

- The approach used for removal of foreign body vary depending on its size, position and proximity to vital structures. As the metal wire was close to the lower border of mandible in the angle region, extraoral submandibular approach was used for the present case. The incision was placed in natural skin crease for cosmetic purpose.
On analysing the case, impaction of foreign body in the submandibular space was due to patient's personal habit of peeling electric wire sheath using his teeth. The sharp wire possibly would have punctured through the oral mucosa over the floor of mouth. The fact that the wire was found in submandibular space, highlights the possibility of its migration. A clinician should be aware that a foreign body impacted within soft tissue can migrate from the site of entry and later be discovered at a distant site. Migration of foreign body, like fish bone and staples within oral and cervical space have been previously reported. ${ }^{12}$ In the present case difficulty in swallowing could be related to the wire impinging on muscles of the floor of mouth and associated soft tissue in the submandibular space. In case of odynophagia with no clinical finding or an obvious cause, patient's personal habits and occupational hazards (like habit of using teeth for peeling electric wire sheath in this case) may give vital clue for diagnosis. ${ }^{3}$ Imaging, using CT scan revealed the foreign body, providing evidence of the cause of odynophagia. ${ }^{56}$ Sectional and three-dimensional formatted CT images further assist to study the size and location of the foreign body, assisting in its surgical removal.

Contributors KN was involved in patient management, surgery, drafting and approval of manuscript.

Funding The author has not declared a specific grant for this research from any funding agency in the public, commercial or not-for-profit sectors.

Competing interests None declared.

Patient consent for publication Obtained.

Provenance and peer review Not commissioned; externally peer reviewed.

\section{REFERENCES}

1 Takaoka K, Hashitani S, Toyohara Y, et al. Migration of a foreign body (staple) from the oral floor to the submandibular space: case report. Br J Oral Maxillofac Surg 2010;48:145-6.

2 Ma J, Sun Y. Migration of an ingested fish bone to the submandibular gland. A Case Report and Literature Review 2019;4:1-4.

3 Peltekis G, Palaskas D, Anyfantakis D, et al. Severe throat pain in patients with negative oropharyngeal examination: four case reports and overview of the literature. Folia Med 2012;54:57-61.

4 Tsujimura T, Inoue M. Evaluation of the association between orofacial pain and dysphagia. J Oral Sci 2020;62:156-9.

5 Nilesh K, V Vande A, K Veerabhadrappa S. Solitary peripheral Ivory osteoma of the mandible presenting with difficulty in deglutition: a case report. J Dent Res Dent Clin Dent Prospects 2017;11:56-60.

6 Ariji Y, Gotoh M, Kimura Y, et al. Odontogenic infection pathway to the submandibular space: imaging assessment. Int J Oral Maxillofac Surg 2002;31:165-9.

Copyright 2020 BMJ Publishing Group. All rights reserved. For permission to reuse any of this content visit

https://www.bmj.com/company/products-services/rights-and-licensing/permissions/

BMJ Case Report Fellows may re-use this article for personal use and teaching without any further permission.

Become a Fellow of BMJ Case Reports today and you can:

- Submit as many cases as you like

- Enjoy fast sympathetic peer review and rapid publication of accepted articles

- Access all the published articles

Re-use any of the published material for personal use and teaching without further permission

Customer Service

If you have any further queries about your subscription, please contact our customer services team on +44 (0) 2071111105 or via email at support@bmj.com.

Visit casereports.bmj.com for more articles like this and to become a Fellow 